ACTA UNIVERSITATIS WRATISLAVIENSIS

PRZEGLĄD PRAWA I ADMINISTRACJI CXX/2

WROCŁAW 2020

https://doi.org/10.19195/0137-1134.120.50

\author{
JACEK GIEZEK \\ ORCID: 0000-0002-0907-5346 \\ Uniwersytet Wrocławski \\ Katedra Prawa Karnego Materialnego
}

\title{
STRONA PODMIOTOWA CZYNU ZABRONIONEGO A FORMY JEGO POPEŁNIENIA — ZAGADNIENIA WYBRANE
}

\begin{abstract}
Abstrakt: Zasadnicza teza opracowania sprowadza się do twierdzenia, że znaczenie stanu świadomości sprawcy czynu zabronionego wzrasta wraz z przesuwaniem kryminalizacji zachowania na przedpole naruszenia dobra prawem chronionego, a także wraz z pojawianiem się rozmaitych form przestępnego współdziałania. Każdej ze zmodyfikowanych form popełnienia czynu zabronionego — zarówno stadialnych, jak i wiążących się z przestępnym współdziałaniem — towarzyszy bowiem wzrost znaczenia elementów składających się na stronę podmiotową. Chodzi przy tym nie tylko o stan świadomości, lecz także o płaszczyznę wolicjonalną. Tendencja taka oznacza, że rekonstrukcja strony podmiotowej w procesie karnym powinna koncentrować się przede wszystkim na tym, czego każdy ze współdziałających chciał i do czego zmierzał, gdyż zewnętrzne zachowanie może zasadzać się na aktywności innych osób, a w rezultacie — podlegać dość daleko idącej redukcji. Można by nawet przyjąć, że to nie zewnętrzne zachowanie, ale stan świadomości osoby współdziałającej w popełnieniu czynu zabronionego decyduje o zakresie jej odpowiedzialności. Tendencji takiej — kryminalnopolitycznie zapewne dobrze uzasadnionej — towarzyszą jednak również pewne komplikacje, wynikające z faktu, że nie jest ona realizowana w sposób do końca konsekwentny. Swoista niekonsekwencja daje o sobie znać, gdy ustawodawca decyduje się na kryminalizowanie zachowań wiążących się z nieumyślnym narażeniem dobra prawnego na niebezpieczeństwo. Problem pojawia się także w wypadku form przestępnego współdziałania, a wyraża się w braku pożądanej symetrii między stanem świadomości i woli osób współdziałających. Nasuwa się bowiem pytanie, czy mamy do czynienia z podżeganiem w rozumieniu art. $18 \S 2$ k.k., jeśli nakłaniający powoduje wykonanie zachowania, które - ze względu na pozostawanie nakłanianego w błędzie — nie może stanowić umyślnego czynu zabronionego, w systemie prawa nie istnieje zaś żaden jego nieumyślny odpowiednik. Przykładem na brak pożądanej symetrii między stanem świadomości i woli osób współdziałających jest również sytuacja, w której mamy do czynienia z udzielaniem w zamiarze ewentualnym pomocy do popełnienia przestępstwa, które przez wykonawcę może zostać popełnione wyłącznie w zamiarze bezpośrednim.
\end{abstract}

Słowa kluczowe: świadomość, strona podmiotowa, zamiar, formy popełnienia przestępstwa, sprawstwo a strona podmiotowa, podżeganie a strona podmiotowa 
Porządkując znamiona czynu zabronionego, z którego popełnieniem wiązana jest odpowiedzialność karna, tradycyjnie wyodrębnia się dwie grupy składających się na jego typizację znamion, a mianowicie znamiona strony przedmiotowej, stanowiące opis zewnętrznego zachowania sprawcy, oraz znamiona strony podmiotowej, będące — najogólniej rzecz ujmując — charakterystyką tworzących niezbędny podkład psychiczny przeżyć, jakie temu zewnętrznemu zachowaniu powinny towarzyszyć. Obie strony czynu - a więc ta wobec sprawcy „zewnętrzna”, nazywana przedmiotową, oraz „wewnętrzna”, bo tkwiąca w jego głowie i z tego względu określana jako podmiotowa - wzajemnie się przenikają, a ich konsekwentne oddzielanie ma dla przedstawicieli dogmatyki prawa karnego walor w pewnym sensie modelujący, a w rezultacie również dydaktyczny. Relatywizm takiego podziału $^{1}$ nie zmienia jednak faktu, że chętnie się nim posługujemy, zwłaszcza że pozwala on na odpowiednie eksponowanie elementów czynu zabronionego, składających się na jego całościowy obraz. Współcześnie nie kwestionujemy też tego, że przykładowo skutek śmiertelny, dający się obiektywnie powiązać z zachowaniem konkretnego sprawcy, podlegać będzie odmiennemu prawnokarnemu wartościowaniu w zależności od tego, czy był wywołany intencjonalnie, czy sprawca spodziewał się jego potencjalnego wystąpienia albo też w ogóle nie dostrzegał takiej możliwości ani jej nie akceptował, a tym bardziej nie chciał, aby się ziściła.

Dokonując w procesie karnym rekonstrukcji zdarzenia, które stanowi podstawę prawnokarnego wartościowania, sąd ma niewątpliwie łatwiejsze zadanie przy ustalaniu faktów istotnych z punktu widzenia znamion strony przedmiotowej. Okoliczności pozwalające na odtworzenie strony podmiotowej — stanowiące niekiedy przedmiot przyjmowanych $\mathrm{w}$ procesie karnym domniemań ${ }^{2}$ — nie są dostępne wprost, lecz są raczej rozmaitymi metodami wyinterpretowywane, miedzy innymi dzięki przyjęciu całkiem racjonalnego i odpowiadającego podstawowej znajomości mechanizmów psychologicznych założenia, że sprawca dysponuje określoną wiedzą oraz doświadczeniem życiowym, a także znane mu są uruchamiane przezeń powiązania kauzalne.

Trudności, o jakich tutaj mowa oraz na jakie — z natury rzeczy — natrafia wymiar sprawiedliwości, nie oznaczają jednak, że podmiotowa strona czynu zabronionego może być traktowana jako mniej ważne dopełnienie całościowego obrazu, a w skrajnych przypadkach nawet lekceważona. Co więcej, w rozważa-

${ }^{1}$ Szerzej na ten temat zob. J. Giezek, Świadomość sprawcy czynu zabronionego, Warszawa 2013, s. $131 \mathrm{n}$.

$2 \mathrm{Na}$ temat znaczenia domniemań w prawie karnym materialnym zob. W. Wróbel, $O$ domniemaniach $w$ zakresie przesłanek odpowiedzialności karnej, „Prace Instytutu Prawa Własności Intelektualnej UJ" 96, 2006, s. 253; M. Gutowski, P. Kardas, Wyktadnia i stosowanie prawa w procesie opartym na Konstytucji, Warszawa 2017, s. 98-99; J. Giezek, Fakty oraz ich ocena jako przedmiot materialnoprawnych domniemań w procesie karnym, [w:] Praworzadność, decentralizacja, przedsiębiorczość. Księga jubileuszowa Profesora Leona Kieresa, red. K. Kiczka, T. Kocowski, W. Małecki, Wrocław 2018, s. 77 n. 
niach dogmatycznych podkreśla się przecież, że pomiędzy stroną przedmiotową a podmiotową powinna istnieć swoista harmonia (w istocie mniej lub bardziej zakłócana w wypadku przestępstw nieumyślnych), w tym oczywiście znaczeniu, że to, co zewnętrzne i odpowiadające znamionom strony przedmiotowej, powinno znaleźć odzwierciedlenie w świadomości sprawcy czynu zabronionego.

Nieuniknione ubytki, jakie występują po stronie podmiotowej przestępstwa nieumyślnego, zdają się prima facie sugerować, że okoliczności odpowiadające znamionom strony przedmiotowej zyskują jednak pewną przewagę i stają się istotniejsze przy konstruowaniu podstaw odpowiedzialności karnej. Rzecz jednak w tym, że gdyby ktoś zechciał wysnuć tego rodzaju wniosek, eksponując w ten sposób dominujące znaczenie strony przedmiotowej, dałoby się go dość łatwo zakwestionować, wskazując przede wszystkim na formy przestępnego współdziałania. Przyglądając się tymże formom — zarówno stadialnym, jak i tym, które wiążą się z przestępnym współdziałaniem — możemy zauważyć pewną nierównowagę między stroną przedmiotową a podmiotową, choć w tym wypadku na korzyść tej drugiej. Rzecz bowiem w tym, że korelacja między stroną przedmiotową a podmiotową - zwłaszcza w przypadku umyślnie popełnianego czynu zabronionego — jest najdalej idąca, gdy mamy do czynienia z czynem, który został popełniony przez jednego sprawcę oraz osiągnął etap dokonania. Strona podmiotowa zaczyna mniej lub bardziej dominować nad przedmiotową w wypadku przestępnego współdziałania oraz na etapach poprzedzających dokonanie.

Formułowana w tym kontekście teza zasadnicza - być może dość banalna, choć warta jednak wyeksponowania — mogłaby zatem brzmieć następująco: znaczenie stanu świadomości sprawcy wzrasta wraz z przesuwaniem kryminalizacji zachowania na przedpole naruszenia dobra chronionego prawem, a także wraz z pojawianiem się rozmaitych form przestępnego współdziałania. Chodzi jednak nie tylko o stan świadomości, lecz także o płaszczyznę wolicjonalną. Dlatego też — nadając wskazanej tezie charakter bardziej uniwersalny — należałoby przyjąć, że każdej ze zmodyfikowanych form popełnienia czynu zabronionego — zarówno stadialnych, jak i wiążących się z przestępnym współdziałaniem — towarzyszy wzrost znaczenia elementów składających się na stronę podmiotową. Można chyba nawet mówić o swoistej odwróconej kaskadowości strony podmiotowej, w tym znaczeniu, że im bardziej oddalamy się od dokonania (względnie naruszenia dobra prawem chronionego), przechodząc do stadiów, jakie leżą na jego przedpolu, lub zastępujemy sprawstwo pojedyncze rozmaitymi formami przestępnego współdziałania (rozpoczynając od współsprawstwa, a kończąc na tak zwanych formach niesprawczych), tym większego znaczenia nabiera strona podmiotowa popełnianego czynu zabronionego ${ }^{3}$.

3 Tę samą myśl można by również ująć następująco: im bardziej oddalamy się od przedmiotowej w swej istocie okoliczności w postaci naruszenia dobra prawnego, tym „więcej” — z perspektywy strony podmiotowej — wymagać powinniśmy od potencjalnego sprawcy (czy współdziałającego w popełnieniu przestępstwa), chcąc pociągnąć go do odpowiedzialności karnej. Oddalanie 
Pojawia się jednak pewna subtelna różnica między formami sytuowanymi na etapach poprzedzających dokonanie a związanymi z przestępnym współdziałaniem, albowiem sygnalizowany tutaj wzrost znaczenia strony podmiotowej w niejednakowym stopniu dotyczy dwóch nakładających się, a jednocześnie koherentnych jej obszarów — świadomości i woli. Świadomość definiowana jako wewnętrzna reprezentacja rzeczywistości, dzięki której podmiot wie, jak — ujmując rzecz najogólniej - wygląda w danej chwili otaczający go świat oraz jakim zmianom obraz tego świata będzie podlegał w bliższej lub dalszej perspektywie, stanowi niezbędne podłoże przy rekonstruowaniu strony podmiotowej czynu zabronionego, lecz sama w sobie jest z pewnością niewystarczająca. Wszak znaczenie ma nie tylko to, co człowiek wie, ale — przyjmując założenie, że aktywnie reguluje swe relacje z otoczeniem - również to, czego chce i do czego zmierza. Jest on bowiem przede wszystkim sprawcą, podejmującym rozmaite działania celowe, których przebieg bywa organizowany przez wiedzę zakodowaną w umyśle i informacje płynące ze środowiska ${ }^{4}$.

Weryfikację tezy o przewadze strony podmiotowej nad przedmiotową w wypadku innych niż dokonane sprawstwo pojedyncze form popełnienia czynu zabronionego warto zatem rozpocząć od nasuwającego się spostrzeżenia, że przewaga ta powstaje albo w obszarze świadomości, albo w obszarze woli. Mówiąc zaś inaczej - sprawca, który znajduje się na etapie przygotowania lub usiłowania czynu zabronionego, więcej chce, niż czyni, natomiast sprawca występujący w jednej z form przestępnego współdziałania więcej wie, niż czyni. O ile zatem formy stadialne wymagają przede wszystkim odpowiedniego ujęcia płaszczyzny wolicjonalnej, wedle zasady, że im dalej od dokonania, tym bliżej do zamiaru bezpośredniego popełnienia czynu zabronionego, o tyle w wypadku form prze-

się od naruszenia dobra prawnego, charakterystyczne wszak dla zachowań występujących na jego przedpolu, które w warstwie zewnętrznej (przedmiotowej) zdają się coraz bardziej neutralne lub wręcz odpowiadają zachowaniom społecznie aprobowanym (na przykład nabywanie używanych w gospodarstwie domowym narzędzi, potencjalnie nadających się do wykorzystania sprzecznego z prawem), musi być kompensowane „złym zamiarem”, zwiększającym lub — być może nawet przesądzającym o bezprawiu popełnianego czynu. Tak, bez wątpienia trafnie, K. Lipiński, Strona podmiotowa pomocnictwa do czynu zabronionego znamiennego wytacznie zamiarem bezpośrednim, „Czasopismo Prawa Karnego i Nauk Penalnych” 21, 2017, nr 2, s. 38 n.

4 J. Kozielecki, Koncepcje psychologiczne człowieka, wyd. 10, Warszawa 2000, s. 213. W literaturze karnistycznej — także mającej charakter podręcznikowy — już od dawna wyodrębnia się dwie płaszczyzny strony podmiotowej, czyli tak zwaną płaszczyznę intelektualną oraz wolicjonalną. Por. np. W. Wróbel, A. Zoll, Polskie prawo karne. Część ogólna, Kraków 2010, s. 204; J. Lachowski, Nauka o przestępstwie. Zasady odpowiedzialności karnej, [w:] System Prawa Karnego, t. 3, red. R. Dębski, wyd. 2, Warszawa 2017, s. 558 n. Niekiedy zwraca się jednak uwagę, że rozdzielenie sfery poznawczej od wolicjonalnej (decyzyjnej) jest sztuczne i nie znajduje oparcia w wiedzy psychologicznej; zob. M. Budyn-Kulig, Umyślność w prawie karnym i psychologii, Warszawa 2015, s. $110 \mathrm{n}$. Rzecz jednak w tym, że nie o rozdzielanie (izolowanie) obu tych sfer chodzi, lecz jedynie o wyeksponowanie zachodzącej między nimi różnicy znaczeniowej. Nikt nie twierdzi przecież, że „wiedzieć” to znaczy tyle samo co „chcieć” lub „mieć zamiar”. 
stępnego współdziałania wzrasta przede wszystkim — choć oczywiście nie tylko ${ }^{5}$ - znaczenie stanu świadomości, skoro sprawca czynu zabronionego obejmować nią musi coraz więcej elementów strony przedmiotowej.

Nieco pełniejsze objaśnienie wyrażonego tutaj poglądu rozpocznijmy od analizy form stadialnych. Możemy wszak znaleźć liczne przykłady czynów zabronionych (zarówno kodeksowych, jak i typizowanych poza kodeksem karnym), których dokonanie może nastąpić albo umyślnie (w zamiarze bezpośrednim lub ewentualnym), albo nieumyślnie. Rzecz charakterystyczna, że nieumyślność ustawodawca zarezerwował wyłącznie dla ostatecznej formy stadialnej, oznaczającej dokonanie, a z różnych powodów nie zdecydował się — skądinąd chyba słusznie - na kryminalizację zatrzymujących się na etapie przeddokonania zachowań nieumyślnych. Dlatego też nawet rażące - a jednocześnie w pełni świadome i zamierzone - naruszenie reguł postępowania $z$ dobrem prawnym, które nie prowadzi jednak do objętego znamionami skutku mającego postać zamierzonego naruszenia lub narażenia dobra na niebezpieczeństwo, nie stanowi czynu zabronionego ${ }^{6}$. Nieco wcześniejsze na iter delicti usiłowanie może być zaś zrealizowane wyłącznie umyślnie, jakkolwiek nie wykluczono w odniesieniu do tego stadium obu postaci umyślności, czyli możliwości zrealizowania go w zamiarze bezpośrednim lub ewentualnym ${ }^{7}$. W wypadku stadium jeszcze bardziej oddalonego od dokonania, a stanowiącego wyjątkowo kryminalizowane przygotowanie, strona podmiotowa została zawężona jedynie do zamiaru bezpośredniego.

Łatwo więc zauważyć, że im bardziej stadia czynu zabronionego oddalone są od dokonania, tym istotniejsza staje się płaszczyzna wolicjonalna, sprawca zaś — wraz ze zwiększaniem się jego dystansu do pełnej realizacji znamion czynu zabronionego - powinien być bardziej zdeterminowany w dążeniu do jego dokonania. Prawidłowość jest bowiem taka, że jeśli negatywny skutek (niejednokrotnie oznaczający naruszenie dobra prawem chronionego) został już wywołany, to fakt, że sprawca być może wcale go nie chciał, nie jest już tak istotny, jak wówczas gdy skutku takiego brakuje, a jego prognozowany obraz istnieje jedynie w wyobraźni sprawcy. Powtórzmy zatem raz jeszcze — im bardziej zwiększamy dystans od dokonania oznaczającego naruszenie dobra prawem chronionego, tym istotniejsza staje się płaszczyzna wolicjonalna, znaczenia nabiera bowiem intencjonalność takiego naruszenia, która — dzięki jego projekcji (wyobrażeniu) — stanowi swoistą

5 Odstępstwo od sygnalizowanej tutaj tendencji stanowi pomocnictwo, które - mimo że bardziej niż sprawstwo oddalone od naruszenia dobra prawnego — może według dominującego poglądu zostać zrealizowane w zamiarze ewentualnym nawet wówczas, gdy czyn, do którego popełnienia pomoc została udzielona, wymaga zamiaru bezpośredniego.

${ }^{6}$ Wyjątek mogą stanowić przestępstwa nieumyślne, mające charakter przestępstw formalnych, jakkolwiek trafny wydaje się postulat, aby ustawodawca wystrzegał się tego rodzaju prawnokarnych typizacji.

7 W odniesieniu do usiłowania trzeba również zauważyć, że zwłaszcza gdy jest ono kwalifikowane jako nieudolne, przewaga strony podmiotowej nad przedmiotową — całkiem już niezależnie od postaci zamiaru — staje się ewidentna. 
rekompensatę elementów strony przedmiotowej. Zdekompletowanym, a w zasadzie jeszcze niezrealizowanym znamionom strony przedmiotowej towarzyszyć bowiem muszą określone plany oraz zamierzenia sprawcy czynu zabronionego i w tym właśnie znaczeniu strona podmiotowa zyskuje nad nią przewagę. Taka prawidłowość zdaje się — ze względów kryminalnopolitycznych — w pełni uzasadniona i dobrze zracjonalizowana.

W przypadku form przestępnego współdziałania różnice pojawiają się już nie tylko na płaszczyźnie wolicjonalnej, lecz — i to chyba nawet przede wszystkim — na płaszczyźnie intelektualnej. Gdy przyglądamy się stronie przedmiotowej oraz podmiotowej czynu zabronionego dokonywanego przez pojedynczego wykonawcę, to — zwłaszcza gdy jest on popełniany umyślnie — dostrzegamy pewną istniejącą między nimi równowagę. Zastępując pojedyncze sprawstwo wykonawcze jakąś formą współdziałania, musimy rozbudowywać o kolejne elementy stan świadomości osoby w różnych formach współdziałającej w popełnieniu czynu zabronionego. Rzecz bowiem w tym, że osoby współdziałające w popełnieniu czynu zabronionego muszą zazwyczaj — w porównaniu z jego pojedynczym wykonawcą — nie tylko więcej okoliczności obejmować swym zamiarem, ale przede wszystkim muszą więcej wiedzieć (na temat aktywności pozostałych uczestników) niż własnoręcznie uczynić.

Jest kilka powodów, aby uznać, że znaczenie stanu świadomości sprawcy czynu zabronionego wzrasta - niekiedy nawet znacząco — jeśli współdziała on w jego popełnieniu z innymi osobami. Odwołując się do najbardziej podstawowej formy takiego współdziałania, jaką jest współsprawstwo, powiedzielibyśmy wszak, że współsprawca często odpowiada nie za to (lub nie tylko za to), co własnoręcznie wykonał, lecz także za to, o czym jedynie wiedział, a co zrobiły osoby z nim współdziałające, nawet jeśli sam — ze względu na podział zadan — w ich aktywności nie uczestniczył. W wypadku współsprawczej realizacji znamion czynu zabronionego dojść więc może do swoistego — w zasadzie niemożliwego przy objętym umyślnością sprawstwie pojedynczym — braku symetrii między składającą się na taki czyn stroną przedmiotową a podmiotową, skoro wiedza o tym, co zrobili inni (powiązana oczywiście z aprobatą dla ich aktywności), staje się wystarczająca. W rezultacie zaś to nie zewnętrzne zachowanie, ale stan świadomości osoby współdziałającej w popełnieniu czynu zabronionego decyduje o zakresie jej odpowiedzialności. Dzieje się tak przede wszystkim dlatego, że w przypadku tej konstrukcji kluczowe znaczenie ma wiążące współsprawców porozumienie, którego charakter jest przecież oczywisty. W doktrynie i judykaturze już dość dawno dostrzeżono, że stanowi ono subiektywny element i jednocześnie niezbędny warunek współsprawstwa, sprowadzający się nie tylko do wzajemnego uzgodnienia przez wszystkich współdziałających woli popełnienia przestępstwa, lecz także świadome współdziałanie co najmniej dwóch osób w akcji przestępnej. Jest więc czynnikiem podmiotowym, który łączy w całość wzajemnie dopełniające się przestępne działania kilku osób, co w konsekwencji pozwala przypisać każdej z nich również tę czynność sprawczą, którą przedsięwzięła 
inna osoba współdziałająca świadomie w popełnieniu przestępstwa ${ }^{8}$. Już z samej istoty porozumienia wynika też konieczność istnienia między umawiającymi się sprawcami wzajemnej subiektywnej więzi, sprowadzającej się do tego, że każdy z uczestników porozumienia musi mieć świadomość tego, iż umawia się z inną osobą co do wspólnego przedsięwzięcia określonych działań oraz deklaruje wolę wspólnego ich wypełnienia, przy czym owa więź subiektywna między sprawcami musi być odniesiona do przedmiotu porozumienia, którym jest wspólne wykonanie czynu zabronionego ${ }^{9}$. Trafne jest zatem twierdzenie, że współsprawstwo charakteryzuje się na gruncie polskiego kodeksu karnego elementem ewidentnie subiektywnym, w odniesieniu do każdego ze współsprawców konieczne jest bowiem ustalenie, że działał on z wolą sprawczą, traktując całość zdarzenia realizowanego przez wszystkich współdziałających jako własne dzieło (animus auctoris) ${ }^{10}$. Dodać od razu należy, że właśnie ta cecha współsprawstwa decyduje o tym, że w większości przypadków — oczywiście w zależności od podziału ról i zadań — osoby współdziałające zazwyczaj więcej wiedzą niż (własnoręcznie) czynią i w tym właśnie znaczeniu strona podmiotowa góruje nad przedmiotową.

Taką tendencję widać jeszcze wyraźniej w wypadku form sprawstwa niewykonawczego. Wszak już w swym założeniu zarówno sprawca kierowniczy, jak i a nawet tym bardziej - sprawca polecający nie wypełnia żadnego z elementów typu określonego w przepisie części szczególnej lub przepisie pozakodeksowym, ograniczając swą aktywność wyłącznie do sterowania zachowaniem innej osoby lub do wydania jej polecenia. Nie może zatem dziwić, że w polskiej doktrynie prawa karnego wyraźnie akcentuje się znaczenie elementu subiektywnego w postaci działania cum animo auctoris, jaki musi się pojawić u kierującego wykonaniem przez inną osobę czynu zabronionego. $\mathrm{O}$ ile jednak panowanie nad przebiegiem realizacji zdarzenia przestępnego $\mathrm{w}$ kontekście świadomości i woli podmiotu sterującego zachowaniem innej osoby przejawia się między innymi w tym, że kierujący ma rzeczywistą i uświadomioną przez siebie możliwość kształtowania i kontrolowania przebiegu całej akcji, o tyle polecenie - nie stanowiąc już tak daleko zakrojonej ingerencji — zawiera w sobie elementy nakłaniania do popełnienia czynu zabronionego oraz opierającą się na komponencie subiektywnym relację zależności, wzmacniającą stanowczość oświadczenia woli polecającego ${ }^{11}$.

Prezentowaną tutaj prawidłowość można zaobserwować także w wypadku tak zwanych form niesprawczych. Jeśli zgodzić się z dominującym w literaturze poglądem, że z dokonanym podżeganiem mamy do czynienia najpóźniej w chwili

8 Zob. wyrok SN z dnia 24 maja 1976 roku, sygn. Rw 189/76, OSNKW 1976, z. 9, poz. 117.

9 Porozumienie przesądza zatem o tym, że każdy ze współdziałających obejmuje świadomością i wolą całość zdarzenia przestępnego, traktując je tak, jak gdyby stanowiło ono w całości rezultat jego zachowania się.

10 P. Kardas, Nauka o przestęstwie. Zasady odpowiedzialności karnej, [w:] System Prawa Karnego, t. 3, s. 969.

11 Ibidem, s. 986, 998. 
wywołania zamiaru popełnienia czynu zabronionego u bezpośredniego wykonawcy, to nie sposób nie zauważyć, że o ile na tak głębokim przedpolu mamy do czynienia ze swoistym ubóstwem elementów strony przedmiotowej, o tyle konieczne jej uzupełnienie musi stanowić rozbudowana strona podmiotowa, bo wzbogacona o nakładający się na siebie stan świadomości podżegacza oraz stan świadomości, jaki podżegacz chciałby wywołać u bezpośredniego wykonawcy. Wszak podżegacz chce, aby inna osoba zechciała zachować się w określony sposób, i do tego, aby ów zamiar wywołać, ogranicza w istocie swoją aktywność.

Przykładem niech będzie przestępstwo kradzieży z włamaniem. Sprawca będący samodzielnym wykonawcą tego przestępstwa musi zrealizować wszystkie znamiona strony przedmiotowej, a ich realizację objąć swoją świadomością, a zatem musi być świadom tego, że podejmowaną przezeń czynnością wykonawczą jest poprzedzony włamaniem (a więc usunięciem jakiegoś zabezpieczenia) zabór przedmiotu, który jest cudzą rzeczą ruchomą. Stan świadomości osoby realizującej w tak zwanej formie niesprawczej znamiona kradzieży z włamaniem, a więc występującej w roli podżegacza lub pomocnika, przedstawia się inaczej i — co można chyba przyjąć — jest znacznie bardziej złożony. Rzecz bowiem w tym, że — przynajmniej co do zasady - podżegacz lub pomocnik musi zdawać sobie sprawę nie tylko ze znaczenia (istoty) własnego zachowania, a więc przede wszystkim z tego, że inną osobę nakłania lub udziela jej pomocy do określonego działania lub zaniechania, lecz także musi być świadom, że to działanie lub zaniechanie stanowi po stronie wykonawcy realizację znamion czynu zabronionego. Podżegacz (a odpowiednio również pomocnik w odniesieniu do czynności stanowiącej ułatwienie), który chce, aby inna osoba dokonała kradzieży z włamaniem, zdaje sobie przecież sprawę, że:

- po pierwsze, nakłania inną osobę do określonego zachowania;

- po drugie, zachowanie, do którego wykonania inna osoba jest nakłaniana, stanowi realizację znamion strony przedmiotowej czynu zabronionego, czyli że w wypadku przestępstwa kradzieży $\mathrm{z}$ włamaniem sprowadza się ono do poprzedzonego usunięciem jakiegoś zabezpieczenia zaboru cudzej rzeczy ruchomej;

- po trzecie wreszcie, nakłaniany obejmuje wywołanym przez podżegającego zamiarem bezpośrednim zabór cudzej rzeczy ruchomej, prowadzący do jej przywłaszczenia.

O ile zatem na stronę przedmiotową podżegania składa się jedynie sama czynność nakłaniania, będącego jakąś formą zewnętrznego oddziaływania na procesy intelektualno-wolicjonalne bezpośredniego wykonawcy, o tyle w obrębie strony podmiotowej, którą współtworzy także stan świadomości osoby nakłanianej, mieści się nie tylko wola wywołania zamiaru (w istocie sprowokowania do określonego zachowania), lecz także świadomość, że w wyniku nakłonienia wykonawca zrealizuje znamiona strony przedmiotowej oraz strony podmiotowej czynu, którego popełnienie jest mu sugerowane ${ }^{12}$.

12 Podobne spostrzeżenia o charakterze konstrukcyjnym mogą dotyczyć również pomocnictwa, którego strona podmiotowa zrelacjonowana jest do dwóch elementów przedmiotowych. 
Jeszcze jeden aspekt w przedstawionym kontekście zasługuje na uwagę. Otóż świadomość sprawcy czynu zabronionego - niezależnie od tego, w jakiej formie jest on popełniany - można podzielić na diagnostyczną oraz prognostyczną ${ }^{13}$. Warto o tym wspomnieć między innymi z tego względu, że współdziałanie w popełnieniu czynu zabronionego - zarówno gdy ma ono postać współsprawstwa (sprawstwa niewykonawczego), jak i podżegania albo pomocnictwa - bywa bardziej lub mniej rozciągnięte w czasie, przy czym aktywność osób współdziałających nie musi być czasowo zbieżna. Ów brak zbieżności może zaś oznaczać, że aktywność ta nie tylko się krzyżuje (gdy pierwsza już trwa, druga dopiero się rozpoczyna, a gdy pierwsza się kończy, druga jest jeszcze kontynuowana), lecz następuje sekwencyjnie - jedna po drugiej. Właśnie owa niejednoczesność zachowań oraz towarzyszących im okoliczności powoduje, że - między innymi w zależności od tego, z jaką formą popełnienia czynu zabronionego mamy do czynienia - prognoza w mniejszym lub większym stopniu będzie dominować nad diagnozą. Prognozowanie istotne jest zwłaszcza przy tak zwanych formach niesprawczych. Podżegacz i pomocnik (a w zasadzie również sprawca polecający), diagnozując to, co osobiście już zrealizowali lub właśnie realizują, czyli obserwując własne zachowania, które mieszczą się na dość zazwyczaj głębokim przedpolu, samo wykonanie czynu zabronionego oraz wywołanie objętego jego znamionami skutku mogą jedynie prognozować. $Z$ perspektywy osób niesprawczo (niewykonawczo) współdziałających w popełnieniu czynu zabronionego nie da się bowiem zdiagnozować zachowania jego wykonawcy, gdyż - z uwagi na sekwencję zdarzeń - takie zachowanie jeszcze nie istnieje, a zatem w rachubę wchodzi jedynie przewidywanie, że wykonawca zrealizuje znamiona czynu zabronionego, w tym że będzie to czynić w sposób z góry założony.

Łatwo zauważyć, że jeśli mamy do czynienia z okolicznościami, których wystąpienie w chwili podejmowania zabronionego zachowania jest jedynie z mniejszym lub większym prawdopodobieństwem prognozowane, łatwo wówczas prognozę — zwłaszcza gdy wyraża się w niej niepewność co do możliwości wystąpienia określonego stanu rzeczy — pomylić z zamiarem ewentualnym. Przewidując przykładowo, że pożądany skutek może jednak nie wystąpić, a podejmując - mimo prakseologicznie negatywnej prognozy — zachowanie potencjalnie do niego prowadzące, sprawca godzi się wszak na to, że jego cel nie zostanie zrealizowany, a tym samym akceptuje również sytuację, w której pożądany stan rzeczy nie wystąpi. Jest to postać godzenia się z faktem, że chcieć nie zawsze znaczy

Udzielający pomocy musi mieć bowiem świadomość tego, że podejmuje czynności stanowiące ułatwienie innej osobie popełnienie czynu zabronionego oraz że czyni to w odniesieniu do konkretnego zachowania, scharakteryzowanego w odpowiednim przepisie części szczególnej lub przepisie pozakodeksowym. Udzielający pomocy musi zatem obejmować świadomością zarówno prawną charakterystykę czynu zabronionego, którego popełnienie ma zamiar ułatwić, jak i mieć świadomość znaczenia swojego zachowania, zwłaszcza tego, że stanowi ono ułatwienie popełnienia przestępstwa przez inną osobę; por. ibidem, s. 1058.

13 Szerzej na ten temat zob. J. Giezek, Świadomość sprawcy..., s. 57 n. 
móc. Z kolei spowodowane brakiem informacji godzenie się na to, że wystąpiły okoliczności podlegające diagnozowaniu, jest jedynie odzwierciedleniem wynikającego z niewiedzy stanu niepewności ${ }^{14}$.

Nie bez znaczenia jest również to, że czyn zabroniony — zarówno gdy analizujemy jego stronę zewnętrzną, jak i korespondujące z nią przeżycia psychiczne — nie jest zdarzeniem statycznym, lecz mniej lub bardziej dynamicznym, a więc rozgrywającym się w określonym (krótszym lub dłuższym) przedziale czasu. Widać to najwyraźniej przy przestępstwach materialnych, których skutek jest niekiedy nawet dość mocno oddalony od prowadzącego doń zachowania, w jakim skłonni jesteśmy upatrywać wypełnienia czynności czasownikowej ${ }^{15}$. Jeśli pytamy zatem o stan świadomości sprawcy czynu zabronionego, musimy zdawać sobie sprawę, że nie mamy tutaj do czynienia z jakimś stanem „zastygłym”, identycznie wyglądającym zarówno w sytuacji początkowej (gdy podejmowany jest zamiar określonego zachowania), jak i w sytuacji końcowej (gdy pojawia się jego wynik). Widać to doskonale przy formach stadialnych, na jakie zwykliśmy dzielić umyślnie popełniany czyn zabroniony. Dynamika zdarzeń, a w konsekwencji również towarzysząca jej zmienność stanów świadomości osób w nich uczestniczących, jeszcze wyraźniej zaznacza się w wypadku przestępnego współdziałania. Obraz rzeczywistości powstający w świadomości współsprawcy, sprawcy kierowniczego lub polecającego, a wreszcie podżegacza lub pomocnika może się różnić ze względu na to, że:

— zazwyczaj nie dotyczy tego samego jej wycinka (fragmentu);

— kształtowany jest w różnych momentach, a więc ewoluuje pod wpływem zachodzących zmian;

— zróżnicowane są predyspozycje poznawcze (zarówno na poziomie sensorycznym, jak i semantycznym), dzięki którym taki obraz powstaje.

Sygnalizowany tutaj mechanizm powoduje wzrost znaczenia strony podmiotowej, której rekonstrukcja w procesie karnym powinna koncentrować się - zwłaszcza w wypadku przestępnego współdziałania — na tym, czego każdy ze współdziałających chciał i do czego zmierzał, gdyż zewnętrzne zachowanie podmiotu współdziałającego na przedpolu może zasadzać się na planowanej (przewidywanej) aktywności innych osób, a w rezultacie — podlegać dość daleko idącej redukcji. Opierająca się na doświadczeniu kauzalnym znajomość powiązań przyczynowych oraz wynikająca z niej zdolność do przewidywania przyszłego przebiegu zdarzeń (umiejętność diagnozowania oraz prognozowania otaczającej nas rzeczywistości) może też sprawić, że dysponujący nią podmiot — wykonując czynności mało spektakularne lub ograniczając je do niezbędnego minimum -

14 Powstać może oczywiście następujące pytanie: jeśli sprawca chce lub nawet pragnie wystąpienia określonego stanu rzeczy, lecz prawdopodobieństwo tego - mimo podjęcia stwarzających lub chociażby minimalnie zwiększających je działań — że pragnienie się ziści, jest raczej niewielkie, to czy mielibyśmy przyjąć, że sprawcy towarzyszy jedynie zamiar ewentualny?

15 Szerzej zob. ibidem, s. $101 \mathrm{n}$. 
przy udziale innych osób doprowadzi do naruszenia dobra prawem chronionego, a w rezultacie zrealizuje znamiona czynu zabronionego. Jest to kolejny argument, który przemawia za tym, że w przypadku przestępnego współdziałania strona podmiotowa, a tym samym również stan świadomości osoby uczestniczącej w popełnieniu czynu zabronionego, zyskuje przewagę nad jej zewnętrzną aktywnością. W pewnym sensie istotniejsze staje się więc nie to, co osoba taka wykonała, ale to, o czym wiedziała i co - w wypadku gdy chcemy jej przypisać przestępstwo umyślne - obejmowała swoim zamiarem. Retorycznie brzmi w tym kontekście pytanie, czy w tej sytuacji stan świadomości osoby współdziałającej w popełnieniu czynu zabronionego można zlekceważyć. Bez obawy o popełnienie błędu możemy wszak stwierdzić, że prawidłowa jego rekonstrukcja staje się poniekąd ważniejsza od tego, co dałoby się odtworzyć dzięki analizie zewnętrznej aktywności każdego ze współdziałających.

Zarysowanej i kryminalnopolitycznie zapewne dobrze uzasadnionej tendencji towarzyszą jednak również pewne komplikacje, wynikające z faktu, że nie jest ona realizowana w sposób zasługujący na aprobatę i do końca konsekwentny. Swoista niekonsekwencja daje o sobie znać, gdy ustawodawca decyduje się na kryminalizowanie zachowań wiążących się z narażeniem dobra prawnego na niebezpieczeństwo. Rzecz bowiem w tym, że narażenie dobra prawnego — niezależnie od tego, czy stanowi ono skutek zachowania sprawcy, czy też jest jedynie abstrakcyjne, a więc charakterystyczne dla przestępstw formalnych — pojawia się niekiedy w typizacjach przestępstw, których stronę podmiotową stanowi nieumyślność. Do przykładów najlepiej ilustrujących podnoszoną tutaj wątpliwość należy chociażby nieumyślne narażenie na niebezpieczeństwo utraty życia lub zdrowia (art. 160 $\S 3$ k.k.), nieumyślne sprowadzenie bezpośredniego niebezpieczeństwa zdarzenia, które zagraża życiu lub zdrowiu wielu osób albo mieniu w wielkich rozmiarach (art. $164 \S 2$ k.k.), czy nieumyślne sprowadzenie bezpośredniego niebezpieczeństwa katastrofy (art. $174 \S 2$ k.k.). Każde z tych przestępstw — głównie z uwagi na dystans, o jaki jego dokonanie jest oddalone od naruszenia chronionego dobra prawnego - jest przejawem kryminalizowania przedpola, pod wieloma względami bardzo podobnego do stadiów przeddokonania czynu zabronionego, którego stypizowanym skutkiem jest właśnie naruszenie owego dobra. Prowadzi to do sytuacji, w której sprawca nieumyślnie narażający dobro prawne realizuje przestępstwo w formie dokonanej, mimo że wie (a tym bardziej obejmuje swym zamiarem) mniej niż sprawca, który świadomie oraz w sposób zamierzony dąży do naruszenia takiego dobra. Oznacza to, że przesuwając kryminalizację zachowania na przedpole naruszenia dobra prawnego, w takim wypadku nie zwiększamy, lecz — wręcz przeciwnie - zmniejszamy wymagania dotyczące strony podmiotowej, zadowalając się nie tylko brakiem woli, ale niekiedy nawet brakiem świadomości, że reguły postępowania $\mathrm{z}$ dobrem prawnym mogły zostać pogwałcone w zagrażający temu dobru sposób. Pewnym pocieszeniem może być to, że w zbiorze zachowań kryminalizowanych nieliczne są przykłady nieumyślnych przestępstw 
formalnych, a więc takich, które wiążą się z abstrakcyjnym zagrożeniem dla dobra prawnego. W wypadku tej grupy przestępstw sygnalizowany tutaj problem jawiłby się jako jeszcze bardziej doniosły, a co więcej — niestety bardziej niepokojący.

Ze stroną podmiotową problem pojawia się także w wypadku form przestępnego współdziałania, przy czym ma on nieco inny charakter. Można by go chyba określić jako brak pożądanej symetrii między stanem świadomości i woli osób współdziałających. Ilustrację mogą stanowić dwa przykłady.

Pierwszy z nich dotyczy podżegania do przestępstwa, którego stroną podmiotową może być wyłącznie umyślność, a więc zamiar bezpośredni lub - co najmniej - ewentualny. Przed przystąpieniem do analizy tego rodzaju sytuacji warto przypomnieć, że — zgodnie z dominującym w literaturze poglądem — znamiona podżegania nie obejmują rzeczywistego zachowania bezpośredniego wykonawcy, lecz jedynie wyobrażony przez nakłaniającego czyn zabroniony, dzięki czemu umyślność lub nieumyślność bezpośredniego wykonawcy pozostaje poza zakresem znamion podżegania, a tym samym nie ma żadnego znaczenia dla przesądzenia umyślności po stronie nakłaniającego ${ }^{16}$. Wcześniej wspomniano już o tym, że podżegacz obejmuje zamiarem (umyślnością) zarówno czynność nakłaniania, jak i wyobrażony czyn zabroniony, natomiast realizację tego czynu może stanowić — zgodnie z zamiarem nakłaniającego — nieumyślne zachowanie bezpośredniego wykonawcy. W konsekwencji zaś podżegacz poniesie odpowiedzialność za umyślne podżeganie, którego znamiona doprecyzowane są przez przepis określający umyślny czyn zabroniony objęty świadomością podżegacza, podczas gdy bezpośredni wykonawca odpowie za zrealizowany przez siebie czyn zabroniony, którego stronę podmiotową kształtować będzie umyślność albo nieumyślność. Realizacja znamion podżegania nie wymaga bowiem wywołania u sprawcy (bezpośredniego wykonawcy) zamiaru popełnienia czynu zabronionego, gdyż wystarczające jest wywołanie zamiaru określonego zachowania, które w wyobrażeniu podżegacza przedstawia się jako czyn zabroniony ${ }^{17}$.

Rzecz jednak w tym, że to klarowne prima facie stanowisko ma jednak pewien słaby punkt, nad którym przechodzi się chyba zbyt łatwo do porządku dziennego, lekceważąc fakt, że efektem nakłaniania nie zawsze będzie przecież wywołanie zamiaru popełnienia czynu zabronionego. Nieodparcie nasuwa się pytanie, czy mamy do czynienia z podżeganiem w rozumieniu art. $18 \S 2$ k.k., jeśli nakłaniający powoduje wykonanie zachowania, które — ze względu na pozostawanie osoby nakłanianej w błędzie — nie może stanowić umyślnego czynu zabronionego, w systemie prawa nie istnieje zaś żaden jego nieumyślny odpowiednik. Przykładem dobrze ilu-

16 Por. zwłaszcza P. Kardas, Teoretyczne podstawy odpowiedzialności karnej za przestępne współdziałanie, Kraków 2001, s. 654 n.

17 Por. A. Wąsek, Kodeks karny. Komentarz, t. 1. Art. 1-31, Gdańsk 1999, s. 268-269; P. Kardas, Teoretyczne podstawy..., s. 654 n.; A. Zoll, [w:] K. Buchała et al., Kodeks karny. Część ogólna. Komentarz do art. 1-116, Kraków 1998, s. 190-191; A. Liszewska, Podżeganie i pomocnictwo a usiłowanie, „Państwo i Prawo” 2000, nr 6, s. 56 n. 
strującym omawianą sytuację może być zachęcenie bezpośredniego wykonawcy, aby zabrał w celu przywłaszczenia rzecz ruchomą, z jednoczesnym wprowadzeniem go w błąd co do tego, że nie jest ona cudza, lecz na przykład niczyja. Punkt wyjścia we wszelkich dotyczących tej kwestii rozważaniach stanowi omówione wcześniej założenie, że zespół znamion czynu zabronionego popełnionego przez podżegacza (odpowiednio pomocnika) składa się z określonych w art. 18 § 2 (lub § 3) k.k. znamion strony podmiotowej (chce, ma zamiar) i przedmiotowej czynu (nakłania, ułatwia) oraz znamion odpowiedniego typu przestępstwa z części szczególnej kodeksu karnego ${ }^{18}$. Trudno uniknąć w pełni zasadnego w tej sytuacji pytania, jak rozumieć określające stronę przedmiotową podżegania znamiona zawarte $\mathrm{w}$ art. $18 \S 2$ k.k.: „nakłania inną osobę do popełnienia czynu zabronionego”, skoro zachowanie sprawcy nie wypełnia znamion żadnego typu czynu zabronionego. Próbując odpowiedzieć na tak postawione pytanie, przyjmuje się w doktrynie, że znamiona podżegania są zrealizowane w chwili, gdy podżegacz nakłania do popełnienia czynu, który w jego świadomości jawi się jako czyn o znamionach określonych w ustawie karnej. Chodzi bowiem o czyn wyobrażony przez podżegacza, a nie o faktycznie wykonany przez sprawcę ${ }^{19}$. Między zachowaniem podżegacza a czynem sprawcy ma bowiem zachodzić tak zwany związek intencjonalny, a czyn sprawcy ,jest tylko punktem odniesienia w świadomości podżegacza (lub pomocnika)"20. O dokonaniu podżegania miałoby więc decydować powstanie u nakłanianego zamiaru wykonania pożądanego przez podżegacza zachowania, „bez konieczności uświadomienia sobie przez osobę nakłanianą, że zachowanie to ma określoną charakterystykę jurydyczną wyrażoną przez odpowiedni przepis kodeksu karnego"21.

Z kilku co najmniej powodów takie rozwiązanie nie wydaje się jednak satysfakcjonujące. Po pierwsze, pożądane przez podżegacza zachowanie nie jest przecież po stronie bezpośredniego wykonawcy — ze względu na brak odpowiednio ukształtowanej strony podmiotowej — czynem zabronionym. Tymczasem $\mathrm{z}$ art. 18 $\S 2$ k.k. wynika jednoznacznie, że o podżeganiu mówimy dopiero wówczas, gdy nakłaniający chce, aby inna osoba dokonała czynu zabronionego, nie zaś jakiegokolwiek prawnokarnie neutralnego zachowania. Zabór cudzej rzeczy, dokonany w przeświadczeniu, że jest ona niczyja, można oczywiście uznać za bezprawny, co

18 A. Liszewska, Współdziałanie przestępne w polskim prawie karnym. Analiza dogmatyczna, Łódź 2004, s. 108.

19 Zob. A. Zoll, Podstawy teoretyczne regulacji współdziałania przestępnego w projekcie kodeksu karnego, „Państwo i Prawo” 1995, nr 6, s. 35; A. Spotowski, Funkcja niebezpieczeństwa w prawie karnym, Warszawa 1990, s. 184; R. Dębski, O teoretycznych podstawach regulacji wspótdziałania przestępnego w kodeksie karnym z 1997 r., „Studia Prawno-Ekonomiczne” 58, 1999, s. 124. Znamiona podżegania wymagają, aby podżegacz miał pełną świadomość normatywnej charakterystyki przedmiotu nakłaniania, nie zawierają natomiast takiego warunku w odniesieniu do osoby nakłanianej, jako że czyn zabroniony stanowiący przedmiot podżegania jest $\mathrm{w}$ istocie jedynie wyobrażony przez podżegacza.

20 R. Dębski, op. cit., s. 120.

21 P. Kardas, Teoretyczne podstawy..., s. 573 n. 
nie oznacza jednak, że podlegać on może — jako czyn zabroniony — prawnokarnemu sankcjonowaniu. Dodać należy, że przepis sformułowany jest w tym zakresie na tyle jednoznacznie i klarownie, że sięganie do wykładni innej niż językowa należałoby uznać za nieuzasadnione.

Po drugie, sprawy nie załatwia także odwołanie się do konstrukcji „związku intencjonalnego", jaki miałby determinować zachowanie podżegacza. Rzecz bowiem w tym, że intencją nakłaniającego nie jest spowodowanie, aby bezpośredni wykonawca dokonał czynu zabronionego, lecz - akurat wręcz przeciwnie - chodzi mu przecież o to, aby jego znamiona (zwłaszcza znamiona strony podmiotowej) nie zostały przez nakłanianego zrealizowane. W przeciwnym razie nie wprowadzałby go w błąd, a w podanym wcześniej przykładzie — nie zapewniałby, że będąca przedmiotem zaboru rzecz jest niczyja. W gruncie rzeczy nakłaniający nie chce, aby nakłaniany dokonał kradzieży, skoro zdaje sobie sprawę, że zachęca do zachowania, które - ze względu na brak po stronie nakłanianego świadomości, że zabierana rzecz stanowi cudzą własność — nie odpowiada istocie kradzieży. W konsekwencji zaś tego rodzaju nakłanianie nie koresponduje z istotą i znaczeniem podżegania.

Po trzecie wreszcie, realizację znamion strony podmiotowej czynu (na przykład przestępstwa kradzieży), którego popełnienie miałoby być objęte związkiem intencjonalnym, przesunęlibyśmy „, głowy bezpośredniego wykonawcy do głowy podżegacza", wypreparowując takie wykonanie z elementów, które decydują o tym, że jest ono prawnokarnie zabronione. Tego rodzaju przesunięcie stałoby w sprzeczności z przyjmowanym powszechnie założeniem, że na zespół znamion czynu zabronionego popełnionego przez podżegacza — oprócz tych, które wynikają $\mathrm{z} w$ art. 18 § 2 k.k. - składa się również objęte zamiarem bezpośrednim dążenie do zrealizowania przez nakłanianego znamion charakteryzujących zarówno stronę przedmiotową, jak i podmiotową takiego czynu, który jest stypizowany jako zabroniony.

Podniesione tutaj argumenty prowadzą do wniosku, że - wbrew prezentowanemu przez część doktryny stanowisku - osoba nakłaniająca do zachowania, które nie odpowiada istocie czynu zabronionego (nie jest na przykład kradzieżą), nie popełnia przestępstwa polegającego na podżeganiu, nawet jeśli towarzyszy jej „zły” zamiar, traktowany jako dopełnienie realizowanych przez bezpośredniego wykonawcę znamion strony przedmiotowej22. Dodać jednocześnie należy, że w wy-

22 Zdając sobie sprawę, że taka konkluzja — zwłaszcza ze względów kryminalnopolitycznych — może wydać się mało satysfakcjonująca, dodatkowo należałoby poddać pod rozwagę wchodzącą w pewnych sytuacjach w rachubę możliwość pociągania do odpowiedzialności karnej tak zwanego podżegacza jako sprawcy bezpośredniego, który osobą nakłanianą do określonego zachowania posłużył się jak „narzędziem”. Odwołując się do nieco przerysowującej rozważaną kwestię ilustracji, powiedzielibyśmy zatem, że status takiego „narzędzia” jakościowo nie różni się w istocie (oczywiście tylko na płaszczyźnie analizowanego zachowania) od statusu na przykład wykorzystywanego przez sprawcę zwierzęcia. Właścicielowi psa, który — szczując zwierzę — doprowadził w ten sposób do pogryzienia sąsiada, nikt nie zarzuci przecież, że podżegał do spowodowania ciężkiego 
padku przestępstw, na których stronę podmiotową składa się zamiar bezpośredni, będący sumą określonego stanu świadomości oraz towarzyszących mu intencji, mamy do czynienia z zachowaniami tak dalece zintegrowanymi, że okoliczności zewnętrznych, w jakich są one realizowane, nie sposób oddzielić od tego, co w głowie sprawcy. W przypadku kradzieży zabór cudzej rzeczy jest tak mocno powiązany ze świadomością, iż jest ona cudza, że znamion tego czynu zabronionego nie da się analizować w sposób wyizolowany, dochodząc do wniosku, że nieświadom tego sprawca „trochę" jakby ukradł, bo przecież zabrał rzecz ruchomą.

Kolejnym przykładem na brak pożądanej symetrii między stanem świadomości i woli osób współdziałających jest sytuacja, w której mamy do czynienia $\mathrm{z}$ udzielaniem $\mathrm{w}$ zamiarze ewentualnym pomocy do popełnienia przestępstwa, które może zostać popełnione wyłącznie w zamiarze bezpośrednim. Rozpowszechniony w doktrynie i judykaturze pogląd, który ma prowadzić do wniosku, że z zamiarem bezpośrednim wykonawcy czynu zabronionego korespondować może zamiar ewentualny pomocnika — nawet jeśli teoretycznie spójny i gwarantujący „czystość” konstrukcji — trudny jest do zaakceptowania z kryminalnopolitycznego punktu widzenia. Argumentów przemawiających przeciwko jego zaakceptowaniu jest niemało, choć wyeksponować warto w tym miejscu dwa najistotniejsze ${ }^{23}$. Przede wszystkim zdumiewać musi sytuacja, w której pomocnictwo „opłaca się" mniej niż współsprawstwo ${ }^{24}$. Współdziałającemu, który w zamiarze ewentualnym zachował się w sposób stanowiący jedynie ułatwienie popełnienia czynu zabronionego (na przykład kradzieży z włamaniem), udałoby się wszak uniknąć odpowiedzialności karnej, gdyby zdołał wykazać — nawiązując chociażby do materialno-obiektywnej koncepcji współsprawstwa - że istotność jego wkładu przekraczała granice pomocnictwa, czyniąc z niego współsprawcę. W celu uniknięcia odpowiedzialności karnej należałoby więc uczynić więcej, a jednocześnie bardziej zbliżyć się do naruszenia dobra prawnego, niż oczekiwalibyśmy tego od pomocnika, co wymyka się przecież jakiejkolwiek sensownej i aksjologicznie trafnej racjonalizacji. Trudno również nie zauważyć, że eksponowana na wstępie tendencja, zgodnie z którą wraz z oddalaniem się od naruszenia dobra prawnego wzrastać powinno znaczenie strony podmiotowej, byłaby w tym wypadku nie tylko odwrócona, lecz w pewnym sensie nawet pogwałcona. Retorycznie brzmi

uszkodzenia ciała, lecz że skutek taki po prostu jako sprawca sam spowodował. Zob. J. Giezek, [w:] Kodeks karny. Część ogólna. Komentarz, red. J. Giezek, Warszawa 2012, s. 176.

23 Szerzej argumentację taką przedstawia K. Lipiński, op. cit., s. $31 \mathrm{n}$.

24 Już przed wieloma laty, a jeszcze na kanwie kodeksu karnego z 1969 roku, Władysław Wolter zwrócił uwagę na to, że „,co jest dobre dla podżegacza lub pomocnika, to tym bardziej nie może być złe dla tego, kto czyni więcej - sam współwykonuje lub kieruje wykonaniem przez inną osobę. Odrzucenie tego poglądu przypominałoby sytuację przed ustanowieniem sprawstwa kierowniczego, kiedy to zachodziła konieczność traktowania jako pomocnika tego, kto czynił znacznie więcej niż tylko pomagał. W rezultacie i tu doprowadziłoby to do pewnej niekonsekwencji, której można uniknąć, stosując odpowiednią argumentację" - idem, [w:] I. Andrejew, W. Świda, W. Wolter, Kodeks karny z komentarzem, Warszawa 1973, s. 106. 
w tym kontekście pytanie, czy „czystość” konstrukcji determinującej regulację form przestępnego współdziałania jest dostatecznym usprawiedliwieniem dla tego rodzaju aksjologicznych niespójności, ocierających się o niedorzeczność.

Dostrzegając zatem różne wymiary i aspekty tych obszarów kryminalizacji, które gotowi bylibyśmy ujmować jako przedpole naruszenia dobra prawnego, oraz zdając sobie sprawę, że - zwłaszcza współcześnie - ujawnia się tendencja do coraz intensywniejszego obejmowania go prawnokarną ochroną, musimy również mieć na uwadze, że dla właściwego określenia bezprawności przestępstw sytuowanych na tak wytyczanym przedpolu coraz większe znacznie odgrywać będzie element subiektywny, który w pewnych sytuacjach może nawet zdominować stronę przedmiotową zabronionego zachowania. Widać to bardzo wyraźnie w przypadku wskazanych wcześniej form stadialnych oraz niesprawczych przestępczego współdziałania, rozmaitych przestępstw formalnych (jak chociażby udziału w zorganizowanej grupie) czy też przestępstw z narażeniem na niebezpieczeństwo abstrakcyjne. W tym kontekście trafna wydaje się również teza o istnieniu wprost proporcjonalnej zależności, którą dałoby się wyrazić w następująco ujętej formule: element subiektywny bezprawności, sytuowany w strukturze normy sankcjonowanej, staje się tym istotniejszy (a nawet ważniejszy od elementu obiektywnego i być może lepiej odzwierciedlający sens bezprawia), im bardziej ochrona dobra prawnego przesuwa się na przedpole jego naruszenia.

W charakterze ogólnie ujętej refleksji trzeba także zauważyć, że skoro akceptujemy fakt kryminalizowania zachowań, które nie stanowią umyślnego sprawstwa pojedynczego, oznaczającego własnoręczne wykonanie kompletu znamion czynu zabronionego (a tym samym jego dokonania), to musimy pogodzić się ze swoistym brakiem symetrii między stroną przedmiotową a podmiotową. Ta pierwsza zyskuje przewagę $\mathrm{w}$ zasadzie wyłącznie $\mathrm{w}$ wypadku przestępstw nieumyślnych (o ile nie są one popełniane we współsprawstwie). Druga, czyli podmiotowa, dominuje natomiast mniej lub bardziej wyraźnie we wszystkich pozostałych przypadkach, odpowiadających rozmaitym formom stadialnym lub powiązanym z przestępnym współdziałaniem. Zasadniczo taką prawidłowość należałoby zaaprobować jako dobrze racjonalizującą podstawy odpowiedzialności karnej. Rzecz jedynie w tym, by ustawodawca był w jej przestrzeganiu konsekwentny, co — jak widać w kontekście przedstawionych przykładów — niestety nie zawsze się udaje.

\section{SUBJECTIVE SIDE OF A PROHIBITED ACT AND FORMS OF ITS COMMITMENT - SELECTED ISSUES}

\section{Summary}

The principal thesis of the study comes down to the contention that meaning of the awareness of the prohibited act perpetrator increases with movement of criminalization of behavior to the 
foreground of infringement of the interest protected by law and also with appearance of various forms of criminal cooperation. It is for each of the modified forms of commitment of a prohibited act - both staged as well as related to criminal cooperation - is accompanied by the increase of meaning of the elements composing the subjective side. It is not only about the state of awareness, but also about the volitional area. This tendency means that reconstruction of the subjective side in the criminal trial should focus first of all on what each of the cooperating persons wanted and what they headed to, as the extrinsic behavior can be founded on activities of other persons and in the result be subject to a far-reaching reduction. It could be even assumed that it is not the extrinsic behavior, but the state of awareness of the person cooperating in committing a prohibited act that decides about the person's responsibility. This tendency — probably well justified from the criminal and political point of view - is also accompanied by some complications that result from the fact that it is not strictly performed to the end. A peculiar lack of consequence is demonstrated when law makers decide for criminalization of behaviors related to unintended exposition to hazard of the interest protected by law. A problem also appears in case of criminal cooperation forms and it is demonstrated by lack of desired symmetry between the state of awareness and will of the cooperating persons, for there is a question if we deal with instigation in the sense of Art. $18 \S 2$ of criminal code, when the instigating person causes performance of the behavior, which - due to suborn person being mistaken - cannot constitute an intentional prohibited act, when in the system of law there is no its unintentional counterpart. An example of lack of the desired symmetry between the state of awareness and the will of the cooperating persons is also the situation in which we deal with participation in conceivable intent of help in committing of a crime, which can be committed by a perpetrator only with direct intent.

Keywords: awareness, subjective side, intension, forms of committing a crime, perpetration vs. subjective side, instigation vs. subjective side

\section{BIBLIOGRAFIA}

Budyn-Kulig M., Umyślność w prawie karnym i psychologii, Warszawa 2015.

Dębski R., O teoretycznych podstawach regulacji współdziałania przestępnego w kodeksie karnym z 1997 r., „Studia Prawno-Ekonomiczne” 58, 1999.

Giezek J., [w:] Kodeks karny. Część ogólna. Komentarz, red. J. Giezek, Warszawa 2012.

Giezek J., Fakty oraz ich ocena jako przedmiot materialnoprawnych domniemań $w$ procesie karnym, [w:] Praworzadność, decentralizacja, przedsiębiorczość. Księga jubileuszowa Profesora Leona Kieresa, red. K. Kiczka, T. Kocowski, W. Małecki, Wrocław 2018.

Giezek J., Świadomość sprawcy czynu zabronionego, Warszawa 2013.

Gutowski M., Kardas P., Wyktadnia i stosowanie prawa w procesie opartym na Konstytucji, Warszawa 2017.

Kardas P., Nauka o przestęsstwie. Zasady odpowiedzialności karnej, [w:] System Prawa Karnego, t. 3, red. R. Dębski, wyd. 2, Warszawa 2017.

Kardas P., Teoretyczne podstawy odpowiedzialności karnej za przestępne współdziałanie, Kraków 2001.

Kozielecki J., Koncepcje psychologiczne czlowieka, wyd. 10, Warszawa 2000.

Lachowski J., Nauka o przestepstwie. Zasady odpowiedzialności karnej, [w:] System Prawa Karnego, t. 3, red. R. Dębski, wyd. 2, Warszawa 2017.

Lipiński K., Strona podmiotowa pomocnictwa do czynu zabronionego znamiennego wyłacznie zamiarem bezpośrednim, „Czasopismo Prawa Karnego i Nauk Penalnych” 21, 2017, nr 2.

Liszewska A., Podżeganie i pomocnictwo a usiłowanie, „Państwo i Prawo” 2000, nr 6. 
Liszewska A., Współdziałanie przestępne w polskim prawie karnym. Analiza dogmatyczna, Łódź 2004.

Spotowski A., Funkcja niebezpieczeństwa w prawie karnym, Warszawa 1990.

Wąsek A., Kodeks karny. Komentarz, t. 1. Art. 1-31, Gdańsk 1999.

Wolter W., [w:] I. Andrejew, W. Świda, W. Wolter, Kodeks karny z komentarzem, Warszawa 1973.

Wróbel W., O domniemaniach $w$ zakresie przesłanek odpowiedzialności karnej, „Prace Instytutu Prawa Własności Intelektualnej UJ" 96, 2006.

Wróbel W., Zoll A., Polskie prawo karne. Część ogólna, Kraków 2010.

Zoll A., [w:] K. Buchała et al., Kodeks karny. Część ogólna. Komentarz do art. 1-116, Kraków 1998.

Zoll A., Podstawy teoretyczne regulacji wspótdziałania przestępnego w projekcie kodeksu karnego, „Państwo i Prawo” 1995, nr 6. 